\title{
Corrigendum: Recent Advances in Lentiviral Vaccines for HIV-1 Infection
}

\author{
Thomas D. Norton ${ }^{1}$ and Elizabeth A. Miller ${ }^{2 *}$ \\ ${ }^{1}$ Department of Medicine, Division of Infectious Diseases, NYU School of Medicine, New York, NY, USA, \\ ${ }^{2}$ Department of Medicine, Division of Infectious Diseases, Icahn School of Medicine at Mount Sinai, New York, NY, USA
}

Keywords: dendritic cells, lentiviral vectors, HIV-1, HIV-1 vaccines, SAMHD1, Vpx

\section{OPEN ACCESS}

Edited and Reviewed by: Mario Clerici,

University of Milan, Italy

${ }^{*}$ Correspondence: Elizabeth A. Miller elizabeth.a.miller@mssm.edu

Specialty section: This article was submitted to HIV and AIDS, a section of the journal

Frontiers in Immunology

Received: 04 August 2016

Accepted: 31 August 2016 Published: 14 September 2016

Citation:

Norton TD and Miller EA (2016) Corrigendum: Recent Advances in Lentiviral Vaccines for HIV-1 Infection.

Front. Immunol. 7:354. doi: 10.3389/fimmu.2016.00354

\section{A corrigendum on}

Recent Advances in Lentiviral Vaccines for HIV-1 Infection

by Norton TD, Miller EA. Front Immunol (2016) 7:243. doi: 10.3389/fimmu.2016.00243

In the original article, an error in the references in the section entitled "Addressing Safety Concerns with LV Vaccine Vectors" is present. Reference number 20 which is cited twice in this section is an error and should instead be Di Nunzio et al. (1).

The authors apologize for this. This error does not change the scientific conclusions of the article in any way.

\section{REFERENCE}

1. Di Nunzio F, Félix T, Arhel NJ, Nisole S, Charneau P, Beignon AS. HIV-derived vectors for therapy and vaccination against HIV. Vaccine (2012) 30:2499-509. doi:10.1016/j.vaccine.2012.01.089

Conflict of Interest Statement: The authors declare that the research was conducted in the absence of any commercial or financial relationships that could be construed as a potential conflict of interest.

Copyright (c) 2016 Norton and Miller. This is an open-access article distributed under the terms of the Creative Commons Attribution License (CC BY). The use, distribution or reproduction in other forums is permitted, provided the original author(s) or licensor are credited and that the original publication in this journal is cited, in accordance with accepted academic practice. No use, distribution or reproduction is permitted which does not comply with these terms. 